\title{
KARAKTERISASI BAKTERI TANAH PERTANIAN ORGANIK DAN TANAH PERTANIAN ANORGANIK DAN UJI ANTAGONIS TERHADAP JAMUR AKAR PUTIH (Rigidoporus microporus)
}

\author{
Widya Lestari, Kamsia Dorliana Sitanggang, Budi Syahputra Munthe \\ Program Studi Agroteknologi, Fakultas Sains dan Teknologi, Universitas Labuhanbatu \\ J1. SM. Raja No. 126A Rantauprapat, Sumatera Utara \\ E-mail :widyalestari1688@gmail.com
}

\begin{abstract}
Research on the Characterization and Antagonist Test of Organic Soil Bacteria and Inorganic Farm Soils Against White Root Fungi (Rigidoporus microporus), was studied at the USU FMIPA Microbiology Laboratory, Medan, in May 2018. The method used was the characterization of agricultural soil bacteria with scatter plates and Yeast media. Extract $1 \%$, obtained 3 soil bacterial isolates namely Sp01, Sp02 and Sp03 and 3 isolates from the inorganic agricultural soils Spa1, Spa2, and Spa3 which were characterized by shape, color, elevation edge and edge of the colony. Sp02 and Sp03 bacteria have greater ability to inhibit the growth of Rigidoporus microporus than Sp01 with inhibition zones of 2.5 and $3.5 \mathrm{~mm}$. Sp al bacterium has the highest inhibitory ability of $30 \mathrm{~mm}$ against Rigidoporus microporus compared to Spa2 and Spa3.
\end{abstract}

Keywords: Bacteria, Rigidoporus microporus, Faarm soils

\section{PENDAHULUAN}

\subsection{Latar Belakang}

Petani di indonesia selalu bakteri yang ada pada tanah pertanian menggunakan bahan kimia dalam pengendalian penyakit jamur akar putih, maka peneliti ingin melakukan penelitian dengan menggunakan isolat bakteri dari tanah pertanian organik dan tanah pertanian anorganik. secara umum didalam tanah pertanian organik dan tanah pertanian anorganik terdapat banyak bakteri, sementara jamur akar putih berkembang di dalam tanah dengan cara menyerang pada bagian akar tanaman, maka peneliti ingin mengkarakterisasi organik dan tanah pertanian anorganik untuk menghambat pertumbuhan jamur akar putih. penyakit akar putih disebabkan oleh jamur yang lazimnya disebut jamur akar putih. Nama ilmiah jamur ini adalah (Rigidoporus microporus) (Klotzsch) Imazeki atau $R$. microporus, meskipun sampai sekarang jamur ini sering dikenal dengan nama Fomes lignosus (Klotzsch) Bres (Semangun, 2000).

Pengendalian penyakit JAP yang lebih ramah lingkungan telah dilaporkan 
sebelumnya misalnya penggunaan tanaman penutup tanah dan pemanfaatan agens biokontrol (ABK). Trichoderma spp. pernah digunakan pada tanaman karet sebagai pupuk biologis dan dilaporkan dapat meningkatkan produksi karet hingga 25\%. Pemanfaatan agens biokontrol seperti Trichoderma spp (Nurhayati, 2011).

Sumatera Utara memiliki luas lahan perkebunan karet sebesar 419.097 hektar dengan total produksi 387.366,04

ton. Terdapat 25 kabupaten di Sumatera Utara yang membudidayakan tanaman karet. Dari daerah-daerah tersebut ada beberapa kabupaten yang menjadi daerah budidaya terluas diantaranya adalah Mandailing Natal, Langkat, Tapanuli Tengah, Tapanuli Selatan, Nias, Padang Lawas Utara, Asahan, Serdang Berdagai, Labuhan Batu dan Simalungun (Badan Pusat Statistik, 2013). Kabupaten Asahan merupakan salah satu sentra perkebunan karet di Sumatera Utara. Produksi karet mengalami penurunan dari 7.934,88 ton pada tahun 2011 menjadi 5.073,79 ton pada tahun 2014 dengan luas lahan 5.252,21 ha (Dinas Kehutanan dan Perkebunan Kabupaten Asahan, 2015). Penurunan hasil produksi karet disebabkan karena adanya penyakit jamur akar putih pada tanaman karet. Untuk itu dicari suatu alternatif pengendalian hayati dengan menggunakan bakteri yang diisolasi dari tanah pertanian organik dan anorganik.

\subsection{Tujuan Penelitian}

1. Untuk mendapatkan isolat bakteri dari tanah pertanian organik dan tanah pertanian anorganik.

2. Mengetahui kemampuan isolat bakteri dari tanah pertanian organik dalam menghambat pertumbuhan jamur akar putih (Rigidoporus microporus).

\subsection{Manfaat Penelitian}

Sebagai bahan informasi dan data awal bagi peneliti dan petani untuk pengendalian jamur akar putih secara biologi.

\section{METODOLOGI PENELITIAN}

\subsection{Tempat Dan Waktu}

Penelitian ini dilakukan pada bulan Mei 2018 sampai Juni 2018 di Laboratorium Mikrobiologi FMIPA Universitas Sumatera Utara (USU) Medan.

\subsection{Bahan Dan Alat}

Alat yang digunakan adalah cawan petri, tabung reaksi, spatula, timbangan analitik, magnetik stirel, aluminium foil, kapas, benang wol, kertas bekas, kertas lebel, cling warp, gelas ukur, beker gelas, pipet tetes, autoclave, vorteks, inkubator, oven, jarum ose lurus, jarum ose bengkok. 
Bahan yang digunakan adalah aquades, media NA (Natrium Agar), blank disk oxoid, alkohol, spiritus, antibiotik dan ketoconazole.

\subsection{Metode Analisa}

Data - data yang didapatkan dari penelitian ini selanjutnya dianalisa secara deskirptif.

\section{PELAKSANAAN PENELITIAN}

\subsection{Lokasi Pengambilan Sampel}

Sampel tanah organik diambil dari lahan pertanian organik yang berada di Desa Tebing Tinggi Kec. Pangkatan Kab. Labuhan Batu, Sumatera Utara dan sampel tanah anorganik di ambil dari pertanian yang berada di Desa Sumber Mulyo, Kec. Marbau, Kab. Labuhanbatu Utara, Sumatera Utara.

\subsection{Pembuatan Media}

Media Nutrient Agar (NA) di timbang 2,8 gram dimasukkan ke dalam erlenmeyer, ditambahkan $100 \mathrm{ml}$ aquades , diaduk dan dipanaskan diatas hotplate sampai mendidih, setelah itu ditutup pakai kapas yang dibungkus aluminium foil diikat pakai benang wol, dibungkus pakai kertas dan dimasukkan ke autoclave, siapkan petri steril, tuang media kedalam petri dan diamkan hingga memadat.

\subsection{Sterilisasi Alat dan Bahan}

Sterilisasi alat dilakukan dengan mencuci bersih dan keringkan alat-alat yang terbuat dari kaca dan keringkan dengan kertas. Kemudian alat-alat tersebut disusun kedalam autoclave. Bahan-bahan yang perlu dilakukan proses sterilisasi juga ikut dimasukan di dalam au toklaf dengan suhu $121^{\circ} \mathrm{C}$ selama 20 menit dengan tekanan 15 psi.

\subsection{Pembuatan Aquadest Steril Untuk Pengenceran}

Disediakan erlenmeyer yang berukuran $1000 \mathrm{ml}$ dimasukan $600 \mathrm{ml}$ air aquadest kemudian ditutup dengan kapas yang telah dilapisin alumunium foil kemudian diikat dengan benang wol kemudian diberi label dimasukan ke dalam outoclave.

\subsection{Isolasi Bakteri Dari Tanah Organik dan Anorganik}

Ditimbang tanah organik sebanyak 10 gram kemudian dimasukan kedalam tabung reaksi pertama yang berisi air aquadest steril $10 \mathrm{ml}$ kemudian divorteks sampai homogen, kemudian ambil $1 \mathrm{ml}$ masukan kedalam tabung reaksi yang kedua berisi air aquadest sebanyak $9 \mathrm{ml}$, lakukan berulang sampai tabung yang ke 6, dari tabung ke 6 diambil sebanyak 0,1 $\mathrm{ml}$ dimasukan ke dalam cawan petri yang berisi media $\mathrm{Na}$ dan disebar dengan hocky 
stick, ditutup dengan kertas dan diberi label kemudian di inkubasi.

Ditimbang tanah anorganik sebanyak 10 gram kemudian dimasukan kedalam tabung reaksi pertama yang berisi air aquadest steril $10 \mathrm{ml}$ kemudian divorteks sampai homogen, kemudian ambil $1 \mathrm{ml}$ masukan kedalam tabung reaksi yang kedua berisi air aquadest sebanyak $9 \mathrm{ml}$, lakukan berulang sampai tabung yang ke 6 , dari tabung ke 6 diambil sebanyak 0,1 ml dimasukan ke dalam cawan petri yang berisi media $\mathrm{Na}$ dan disebar dengan hocky stick, ditutup dengan kertas dan diberi label kemudian diinkubasi.

\subsection{Uji Antagonis Bakteri Tanah}

\section{Organik dan Anorganik}

Ditimbang media Nutrient Agar NA 2,8 gram ke dalam erlenmeyer, setelah itu ditambahkan aquadest $100 \mathrm{ml}$, di aduk dipanaskan diatas hote plate. Setelah itu dimasukan ke dalam autoclave untuk diseterilkan.

Disiapkan petri steril, dituang media NA ke dalam petri didiamkan hingga memadat setelah itu dibuat garis kuadrat. Siapkan jamur akar putih diambil dengan cork boror, setelah itu di inokulasikan jamur akar putih (Rigidoporus microporus) ke dalam petri yang mau di uji antagonis. Setelah diinkubasi di dalam inkubator, hari ke-3 baru di inokulasikan bakteri hasil isolasi dari tanah organik dan anorganik dilakukan pengamatan.

\subsection{Karakterisasi Morfologi Isolat}

\section{Bakteri}

Isolat bakteri yang diperoleh dari tanah pertanian organik dan tanah pertanian anorganik dikarakterisasi secara morfologi meliputi bentuk, warna, elevasi, tepi koloni.

\subsection{Subkultur Bakteri}

Ditimbang media Nutrien Agar (NA) 2,8 gram masukkan ke dalam erlenmeyer Setelah itu tambahkan Aquadest $100 \mathrm{ml}$ dimasukan ke dalam erlenmeyer diaduk dipanaskan diatas hote plate, kemudian dimasukan ke kedalam autoclave untuk disterilkan. Disiapkan petri steril, dituang media Nutrient Agar (NA) ke dalam petri di diamkan hingga memadat setelah itu diambil bakteri dari petri isolasi awal untuk disubkultur agar mendapatkan biakan murni.

\section{HASIL DAN PEMBAHASAN}

\subsection{Hasil Isolasi Bakteri Dari Tanah Organik}

Dari hasil isolasi diperoleh sebanyak 3 isolat bakteri dari tanah organik yaitu Spo1, Spo2, dan Spo3, selanjutnya dilakukan karakterisasi morfologi bakteri (Tabel 4.1.1). 
Tabel 4.1.1. Karakterisasi Morfologi Tanah Organik

\begin{tabular}{|c|c|c|c|c|c|}
\hline No. & Spesies & Bentuk & Tepi & Elevasi & Warna \\
\hline 1 & Spo 1 & $\begin{array}{c}\text { Bulat } \\
\text { (Circular) }\end{array}$ & $\begin{array}{c}\text { Rata } \\
\text { (Entire) }\end{array}$ & $\begin{array}{l}\text { Cembung } \\
\text { (Raised) }\end{array}$ & Kuning \\
\hline 2 & Spo 2 & $\begin{array}{l}\text { Berbenang } \\
\text { (Filamentous }\end{array}$ & $\begin{array}{l}\text { Bergelombang } \\
\text { (Undulate) }\end{array}$ & $\begin{array}{l}\text { Datar } \\
(\text { Flat })\end{array}$ & Putih Susu \\
\hline 3 & Spo 3 & $\begin{array}{l}\text { Tidak Beraturan } \\
\text { (Iregular) }\end{array}$ & $\begin{array}{l}\text { Berlobus } \\
\text { (Lobate) }\end{array}$ & $\begin{array}{l}\text { Datar } \\
\text { (Flat) }\end{array}$ & Putih Susu \\
\hline
\end{tabular}

\subsection{Hasil Isolasi Bakteri Dari Tanah Anorganik}

Dari hasil isolasi diperoleh sebanyak 3 isolat bakteri dari tanah anorganik yaitu Spa1, Spa2, dan Spa3, selanjutnya dilakukan karakterisasi morfologi bakteri (Tabel 4.2.1).

Tabel 4.2.1 Karakterisasi Morfologi Tanah Anorganik

\begin{tabular}{cccccc}
\hline No & Spesies & Bentuk & Tepi & Elevasi & Warna \\
\hline 1 & Spa1 & $\begin{array}{c}\text { Seperti Akar } \\
(\text { Rhizoid })\end{array}$ & Curled & $\begin{array}{l}\text { Datar } \\
\text { (Flat) }\end{array}$ & Putih Kekuningan \\
2 & Spa2 & $\begin{array}{c}\text { Bulat } \\
(\text { Circuar })\end{array}$ & $\begin{array}{c}\text { Rata } \\
\text { (Entire })\end{array}$ & $\begin{array}{l}\text { Datar } \\
(\text { Flat })\end{array}$ & Putih \\
3 & Spa3 & $\begin{array}{c}\text { Bulat } \\
\text { (Circular })\end{array}$ & $\begin{array}{c}\text { Rata } \\
(\text { Entire })\end{array}$ & $\begin{array}{l}\text { Cembung } \\
(\text { Raised })\end{array}$ & Kuning \\
\hline
\end{tabular}




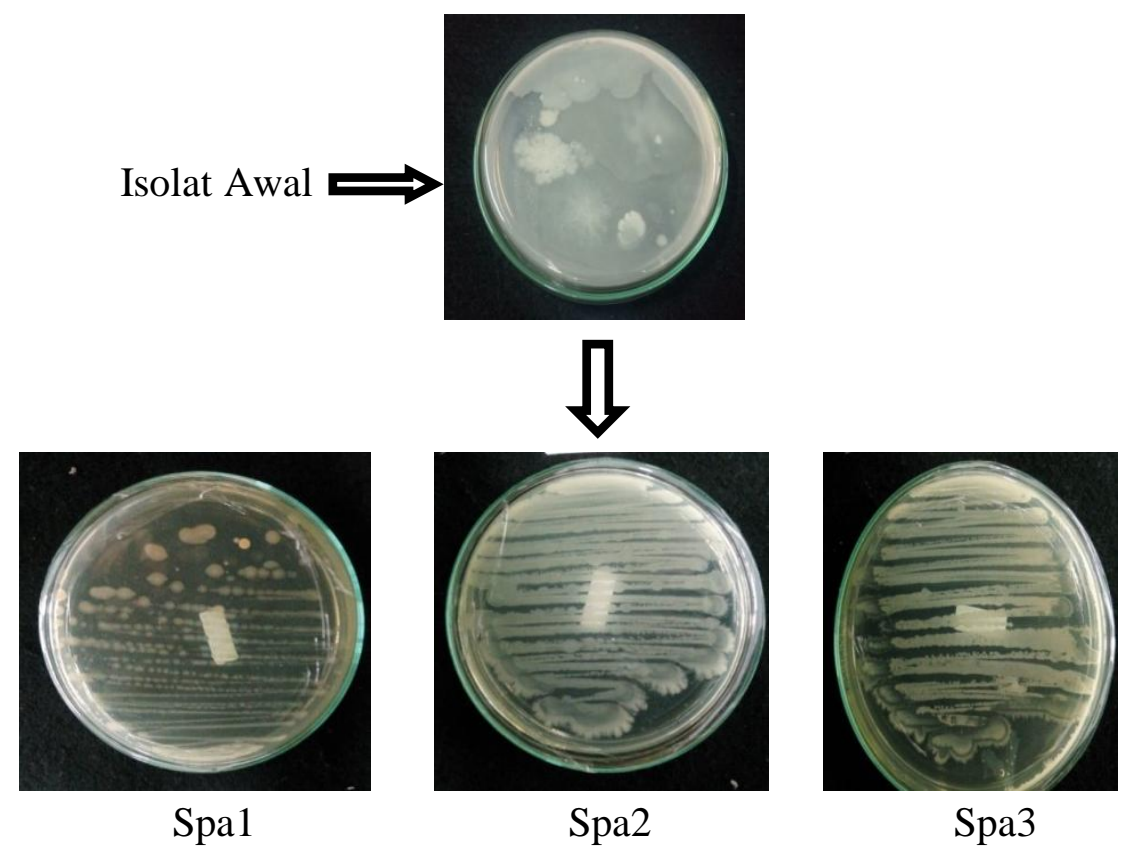

\subsection{Identifikasi Morfologi Bakteri}

Isolasi bakteri ini dilakukan bertujuan untuk memisahkan dan membiakkan bakteri yang terdapat di dalam campuran dengan menggunakan media kultur sehingga diperoleh isolat bakteri atau biakkan murni dari bakteri tersebut (Darwis dan Sukar, 1999).

Pada proses isolasi ini media isolasi spesifik yang digunakan adalah media NA (Nutrient Agar), Media selektif ini digunakan untuk menumbuhkan dan memelihara bakteri tertentu, dengan sifat kekhususannya tersebut, maka media ini akan menyeleksi bakteri yang ingin ditumbuhkan yaitu Bakteri Tanah Organik dan Anorganik.

\subsection{Hasil Uji Antagonis Bakteri Tanah} Organik ( TO ) Dan Anorganik ( TA )

Kemampuan antagonis bakteri tanah organik dan anorganik terhadap jamur akar putih ( $R$. microporus ) isolat bakteri Spa1, Spa2, dan Spa3 digunakan pada uji antagonis untuk melihat kemampuannya dalam menghambat pertumbuhan jamur akar putih ( $R$. microporus ) (Gambar 4.4.1). 


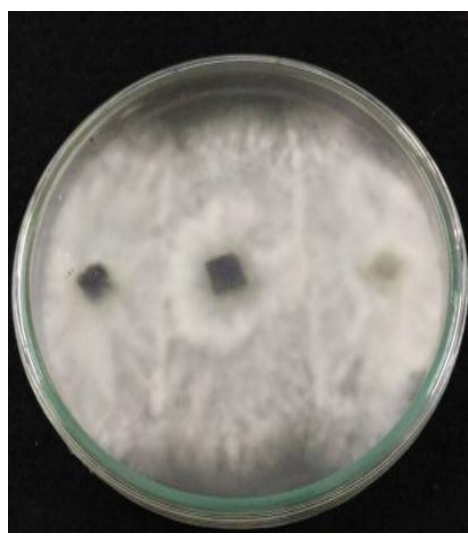

TO Spo1

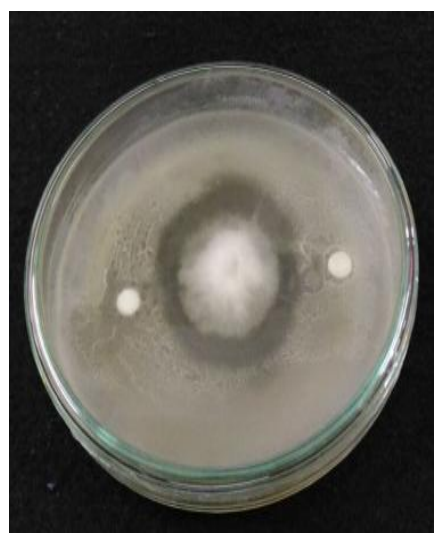

TO Spo2

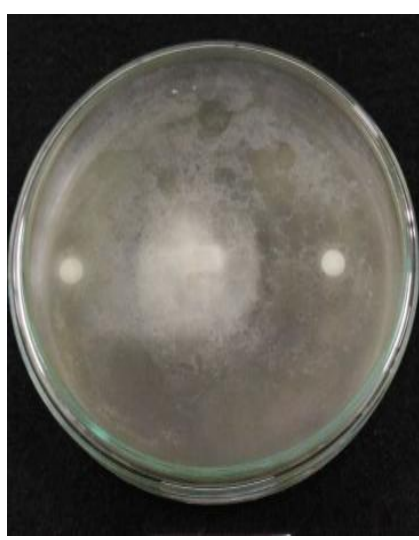

TO Spo3

Gambar 4.4.1 Zona hambat isolat bakteri tanah organik, (a) merupakan zona hambat isolat bakteri tanah organik Spo1 terhadap jamur R. microporus dengan zona hambat sebesar Y 90 $\mathrm{mm}$ dan X $90 \mathrm{~mm}$. (b) merupakan zona hambat isolat bakteri tanah organik Spo2 terhadap jamur $R$. microporus dengan zona hambat sebesar Y $31 \mathrm{~mm}$ dan X $26 \mathrm{~mm}$. (c) merupakan zona hambat isolat bakteri tanah organik Spo3 terhadap jamur $R$. microporus dengan zona hambat sebesar Y $40 \mathrm{~mm}$ dan X $33 \mathrm{~mm}$.

Tabel 4.4.2 Hasil Uji Antagonis Bakteri Tanah Organik

\begin{tabular}{llllcc}
\hline No. & Spesies & $\begin{array}{c}\text { Diameter } \\
\mathbf{Y}(\mathbf{m m})\end{array}$ & $\begin{array}{c}\text { Diameter } \\
\mathbf{X}(\mathbf{m m})\end{array}$ & $\frac{\mathbf{Y}-\mathbf{X}}{\mathbf{2}}$ & $\begin{array}{c}\text { Indeks Zona } \\
\text { Hambat }(\mathbf{m m})\end{array}$ \\
\hline 1. & Spo1 & 90 & 90 & $\frac{90-90}{2}$ & 0 \\
2. Spo2 & 31 & 26 & $\frac{31-26}{2}$ & 2,5 \\
3. & Spo3 & 40 & 33 & $\frac{40-33}{2}$ & 3,5 \\
\hline
\end{tabular}

Dari Tabel 4.4.2 dapat dilihat bahwa zona hambat hasil uji antagonis dari masing masing isolat bakteri tanah pertanian organik terhadap jamur akar putih $R$. microporus bervariasi. Hal ini mungkin disebabkan karena bakteri tanah pertanian organik menghasilkan senyawa metabolit sekunder yang berbeda beda. Mikroba yang memiliki kemampuan sebagai antimikroba dapat menghasilkan senyawa antimikroba yang merupakan metabolit sekunder yang tidak digunakan lagi untuk proses pertumbuhan (Schlegel, 1993), tetapi untuk pertahanan diri dan kompetisi dengan mikroba lain dalam mendapatkan nutrisi, habitat, oksigen dan lain-lain. Senyawa antimikroba tersebut dapat dikelompokkan sebagai antibakteri dan antifungi (Cook \& Baker 1974).

Mikroba khususnya bakteri memiliki kemampuan menghambat pertumbuhan mikroba lain disebabkan karena bakteri 
dapat menghasilkan senyawa metabolit sekunder seperti senyawa antimikroba, antibiotik (Wright et al., 2001), enzim pelisis (Zhang \& Yuen, 2000; Kim et al., 2008) dan protein penghambat lain (Berdy, 2005; Borodina et al., 2005; Lestari, 2001; Price et al., 1999).

Bakteri yang memiliki zona hambat paling besar adalah bakteri Sp3 yang dapat menghambat jamur akar putih $R$. microporus dengan zona hambat yang berkisar $3.5 \mathrm{~mm}$. Menurut Bakri (2009), Isolat bakteri tersebut memiliki kemampuan antagonistik yang ditandai dengan adanya penghambatan miselium jamur patogen tanaman dan pada akhirnya pertumbuhan hifa menipis, mengering dan mengalami abnormalitas.

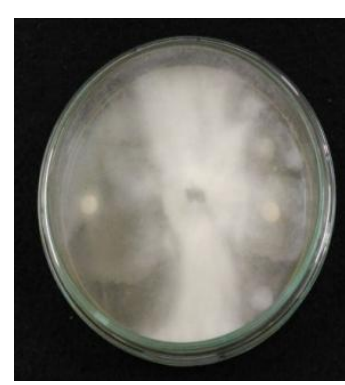

Gambar TA Spa.1

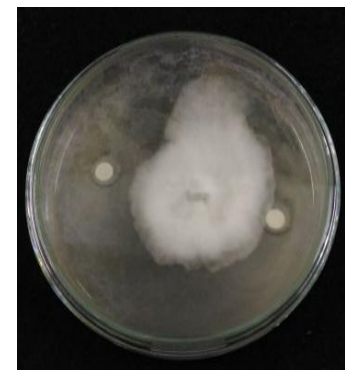

Gambar TA Spa.2

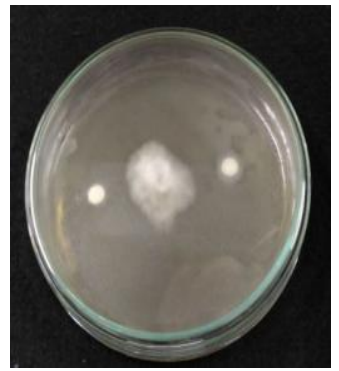

Gambar TA Spa.3

Gambar 4.4.3 Zona hambat isolat bakteri tanah organik, (a) merupakan zona hambat isolat bakteri tanah organik Spa1 terhadap jamur $R$. microporus dengan zona hambat sebesar Y 89 $\mathrm{mm}$ dan X $29 \mathrm{~mm}$. (b) merupakan zona hambat isolat bakteri tanah organik Spa2 terhadap jamur $R$. microporus dengan zona hambat sebesar Y $66 \mathrm{~mm}$ dan X $48 \mathrm{~mm}$. (c) merupakan zona hambat isolat bakteri tanah organik Spa3 terhadap jamur $R$. microporus dengan zona hambat sebesar Y $30 \mathrm{~mm}$ dan X $22 \mathrm{~mm}$.

Tabel 4.4.4 Hasil Uji Antagonis Bakteri Tanah Anorganik

\begin{tabular}{lccccc}
\hline No. & Spesies & $\begin{array}{c}\text { Diameter } \\
\text { Y (mm) }\end{array}$ & $\begin{array}{c}\text { Diameter } \\
\mathbf{X}(\mathbf{m m})\end{array}$ & $\frac{\mathbf{Y}-\mathbf{X}}{\mathbf{2}}$ & $\begin{array}{c}\text { Indeks Zona } \\
\text { Hambat }(\mathbf{m m})\end{array}$ \\
\hline 1. & Spa1 & 89 & 29 & $\frac{89-29}{2}$ & 30 \\
1. & Spa2 & 66 & 48 & $\frac{66-48}{2}$ & 9 \\
2. & Spa3 & 30 & 22 & $\frac{30-22}{2}$ & 4 \\
\hline
\end{tabular}

Dari Tabel 4.4.4 dapat dilihat bahwa zona hambat hasil uji antagonis dari masing masing isolat bakteri tanah pertanian anorganik terhadap jamur akar putih $R$. microporus bervariasi. Hal ini mungkin disebabkan karena bakteri tanah 
pertanian organik menghasilkan senyawa metabolit sekunder yang berbeda beda. Mikroba yang memiliki kemampuan sebagai antimikroba dapat menghasilkan senyawa antimikroba yang merupakan metabolit sekunder yang tidak digunakan lagi untuk proses pertumbuhan (Schlegel, 1993), tetapi untuk pertahanan diri dan kompetisi dengan mikroba lain dalam mendapatkan nutrisi, habitat, oksigen dan lain-lain. Senyawa antimikroba tersebut dapat dikelompokkan sebagai antibakteri dan antifungi (Cook \& Baker 1974).

Mikroba khususnya bakteri memiliki kemampuan menghambat pertumbuhan mikroba lain disebabkan karena bakteri dapat menghasilkan senyawa metabolit sekunder seperti senyawa antimikroba, antibiotik (Wright $e t$ al., 2001), enzim pelisis (Zhang \& Yuen, 2000; Kim et al., 2008) dan protein penghambat lain (Berdy, 2005; Borodina et al., 2005; Lestari, 2001; Price et al., 1999).

Isolat bakteri yang diujikan menunjukkan kemampuan menghambat jamur patogen $R$. Microporus. Hal ini mungkin disebabkan karena pegaruh perbedaan dinding sel penyusun dari jamur yang digunakan dalam uji antagonis. Bakteri yang memiliki zona hambat paling besar adalah bakteri Spa1 yang dapat menghambat jamur akar putih $R$. microporus dengan zona hambat yang berkisar $30 \mathrm{~mm}$. Menurut Bakri (2009), Isolat bakteri tersebut memiliki kemampuan antagonistik yang ditandai dengan adanya penghambatan miselium jamur patogen tanaman dan pada akhirnya pertumbuhan hifa menipis, mengering dan mengalami abnormalitas.

Belum seluruhnya dapat dijelaskan dengan cara bagaimana mikroorganisme antagonis mempengaruhi populasi patogen, tetapi umumnya mekanisme tersebut dihubungkan dengan salah satu dari empat pengaruh yaitu (1) parasitisme dan membunuh patogen secara langsung; (2) berkompetisi dengan patogen dalam hal makanan; (3) toksin yang langsung mempengaruhi patogen dengan zat antibiotic yang dilepaskan oleh antagonis; dan (4) toksin yang tidak langsung mempengaruhi patogen melalui zat yang mudah menguap, seperti etilen, yang dilepaskan oleh aktivitas metabolic antagonis (Agrios, 1997). 


\section{KESIMPULAN DAN SARAN}

\subsection{Kesimpulan}

1. Diperoleh 3 isolat bakteri dari isolasi tanah organik yaitu Sp 01, Sp 02, Sp 03. Sp 01 berbentuk bulat tepiannya rata elevasi cembung dan berwarna kuning. Sp 02 berbentuk berbenang tepiannya bergelombang elevasi data dan berwarna putih susu. Sp 03 berbentuk tidak beraturan tepiannya berlobus elevasi datar dan berwarna putih susu.

2. Diperoleh 3 isolat bakteri dari isolasi tanah anorganik yaitu $\mathrm{Sp}$ a1, Sp a2, Sp a3. Sp a1 berbentuk seperti akar tepiannya bergelombang elevasi datar dan berwarna putih kekuningan. Sp a2 berbentuk bulat tepiannya rata elevasi datar dan berwarna putih. Sp a3 berbentuk bulat tepiannya rata elevasi cembung dan berwarna kuning.

\subsection{Saran}

Perlu dilakukan uji antagonis terhadap jamur Ganoderma boninense yang menyebabkan penyakit tanaman kelapa sawit.

\section{DAFTAR PUSTAKA}

Agrios, G. N. 1997. Plant Pathology 4Edition. Academic Press, New York.

Baker, K.F dan Cook, R.J. 1999. The Nature dan Practice of Biological Control of Plant Pathogens. 3rd Edition: The American Phytopathology Society.

Bakri, M. 2009. Isolasi dan Uji Kemampuan Antifungal Fungi Endofit dari Tanaman Andaliman (Zanthoxylum acanthopodium DC.) Terhadap Fungi Perusak Makanan. Skripsi. USU. Medan.

Borodina, I., Krabben, $\mathrm{P}$ dan Nielsen, J. 2005. Genome Scale Analysis of Streptomyces coelicolor A3(2) Metabolism. Genome Research.15: 820-829.

Badan Pusat Statistik (BPS). 2013. Sumatera Utara dalam Angka 2013. Medan

Darwis dan Sukara. 1999. Isolasi Purifikasi dan Karakterisasi Enzim. Bogor: IPB.

Dinas Kehutanan dan Perkebunan Kabupaten Asahan. 2015. Daftar luas Areal dan Produksi Tanaman Karet Kapupaten Asahan, Asahan.

Nurhayati, 2011. Penggunaan jamur dan bakteri dalam pengendalian penyakit tanaman secara hayati yang ramah lingkungan. Prosiding Semirata Bidang Ilmu-Ilmu Pertanian BKS-PTN Wilayah Barat 316-321.

Semangun, Haryono, 2000. Pengantar Ilmu Penyakit Tumbuhan. Gadjah Mada University. Yogyakarta. 
Zhang, $Z$ and Yuen, G.Y. 2000. Effects of Culture Fluids and Preinduction of Chitinase Production on
Biocontrol of Bipolaris lLeaf Spot by Stenotrophomonas maltophilia C3. Biol Contr 18: 277-286. 